\title{
Government Preparedness and Response for 2020 Pandemic Disaster in Nepal: A Case Study of COVID-19
}

\author{
Dr. Jyoti Koirala, Tribhuvan University - Kathford International College of Engineering and Management \\ Dr. Suman Acharya, Central Bank of Nepal / Tribhuvan University - National Law College \\ Dr. Madhusudan Neupane, Tribhuvan University - Bajra International College \\ Dr. Motiram Phuyal, Tribhuvan University - Kutumba College of Management and Humanities Studies \\ Dr. Nimananda Rijal, Kathmandu University - School of Education \\ Dr. Umesh Prasad Khanal, Tribhuvan University - Teaching Hospital
}

Date of Submission: 30/March/2020

\begin{abstract}
:
The outbreak of Nobel Corona Virus (COVID-19) from Wuhan has isolated millions of population from regular activities. The spread is so much viral that it is almost impossible to stop (WHO, 2020). It is important to understand the role of Government, Business Houses and Development Partners in understanding the effectiveness in immediate preparedness and response of the situation. The main purpose of this study is to explore and understand the overall management of situation based in experience of Italy, China, USA and South Korea after the outbreak of Corona Virus. The overall aim of the study is to draw the clinical expertise, field experience to identify the needs and gaps and make recommendation for effective preparedness and response. China is already experienced in controlling such pandemic situation from the time of outbreak of SARS in 2002-2003. This time it is not that much difficult for government to set up large scale surveillance system in identifying and following up the suspected and infected people. Although South Korea didn't follow lockdown method, it made quick preventive and curative method. Identification of this viral disease is made within an hour by using telephone booth and public place in each nook and corner of the country. However, Italy and US didn't make preparation once COVID-19 outbreak was there in China and still rejects country lockdown method. Since the country has been facing the situation of lockdown and all the respondents have become bound to their home depending on the information sources basically social network and online news and in little extent print and digital media. Their responses reflect the availability of figures accessible to them and it certainly has the impact over the result thus obtained. A huge gap in response obtained due to the fluctuations in knowledge has been evident for a set of questionnaire. Government of Nepal made specialised hospitals in capital and various provinces of the country, which helps to check viral effect in time. As economic activities are zero, the facilities and relief packages are necessary to grant to all sectors of the country to revitalise the economy. In case of the number of cases are increased, it is alarmingly difficult to control. With the decision of country lock-down, it has both positive and negative impact. But this policy cannot sustain for longer period of time and is only short term measures.
\end{abstract}

\section{Background of the Study}

The word pandemic itself is a disaster. According to Medicine Net (2020), "Pandemic is an epidemic (a sudden outbreak) that becomes very widespread and affects a whole region, a continent, or the world due to a susceptible population. By definition, a true pandemic causes a high degree of mortality (death)." It further states that the word "pandemic" comes from the Greek "pan-", "all" + "demos," "people or population" = "pandemos" = "all the people." A pandemic affects all (nearly all) of the people. By contrast, "epi-" means "upon." An epidemic is visited upon the people. And "en-" means "in." An endemic is in the people. Understanding the word itself gives the details about its huge impact throughout the world. 
WHO (2020) says that "coronaviruses are a large family of viruses that are known to cause illness ranging from the common cold to more severe diseases such as Middle East Respiratory Syndrome (MERS) and Severe Acute Respiratory Syndrome (SARS)." A novel coronavirus (COVID-19) was identified in 2019 in Wuhan, China. This is a new coronavirus that has not been previously identified in humans. This course provides a general introduction to COVID-19 and emerging respiratory viruses and is intended for public health professionals, incident managers and personnel working for the United Nations, international organizations and NGOs.

\section{Objectives of the Study}

Globally disasters have increasing day by day. Each year massive disaster events of pandemic, epidemic, earthquake, floods, drought, heat waves, cyclones and tsunamis happening and killing thousands of people and causing the billions of economic losses around the world. Huge damage is occurring affecting millions of population around the globe. Recent outbreak of Nobel Corona Virus (COVID-19) from Wuhan has isolated millions of population from regular activities. The spread is so much viral that it is almost impossible to stop (WHO, 2020). It is important to understand the role of Government, Business Houses and Development Partners in understanding the effectiveness in immediate preparedness and response of the situation.

In Nepal, the concept of controlling the situation has garnered immense attention from Governmental bodies, Non-Governmental bodies, partner agencies, political parties, different professionals, resident and non-resident Nepalese Citizens, foreign citizens, Red Cross, academicians and practitioners. In this context it is necessary to understand how the country response in the large disaster of deaths, displacements and disease.

The main purpose of this study is to explore and understand the overall management of situation based in experience of Italy, China, USA and South Korea after the outbreak of Corona Virus. The overall aim of the study is to draw the clinical expertise, field experience to identify the needs and gaps and make recommendation for effective preparedness and response.

The different objectives to be dealt in this study are:

a) To explore and understand the overall management of situation

b) To evaluate the preparedness and response of government activities

c) To identify the major gaps and issues in functioning the controlling activities

d) To recommend the authority for immediate actions.

The issues dealt in the research will be guided by the following research questions.

a) What is the overall preparedness and response mechanism for this pandemic?

b) How the general public felt the situation and about government?

c) What are the gaps and issues in functioning the activities?

d) What are the recommendations for immediate action to government?

Though there are handful of studies being carried out in similar studies, most of the studies have been carried out on developed economies. Not a single study has been conducted by Nepalese Government including donor agencies on this. With these limited studies it is not sure whether the conclusions carried out in developed countries are valid for developing countries like Nepal too or different sets of factors influence the disaster. Hence this study aims to critically evaluate preparedness and response of government during the outbreak.

\section{Strategic Preparedness and Response Plan}

In the last day of December, 2019 WHO alerted to a cluster of pneumonia patients in Wuhan City, China. Within 7 days, authorities identified the coronavirus as cause of the pneumonia and its name has been proposed as 2017nCoV. Within 1 February 2020 total number of 11953 confirmed cases of 2019-nCoV have been reported worldwide. WHO assess and commented as high risk and alerted the world as likelihood of further spread throughout the world. Once WHO warned the world as pandemic, every country come up with preparedness and response plan to stop further transmission of $2019-\mathrm{nCoV}$ in China and other countries to mitigate the impact of the outbreak in all countries. After the outbreak and its spread is wide, countries established multi-sectorial contingency plan at points and also conducted the exercise to assess the operational applicability of such plans. 
Table 1: WHO recommended Strategic Preparedness and Response Plan

\begin{tabular}{|c|l|c|l|}
\hline SN & \multicolumn{1}{|c|}{ Emergency Plans } & SN & \multicolumn{1}{c|}{ Emergency Plans } \\
\hline 1 & Point of Entry & 6 & $\begin{array}{l}\text { Logistic, Procurement and Supply } \\
\text { Management }\end{array}$ \\
\hline 2 & Rapid Response Team & 7 & $\begin{array}{l}\text { Accelerating priority research and } \\
\text { innovation through global coordination } \\
\text { and standardization of process }\end{array}$ \\
\hline 3 & National Laboratory System & 8 & $\begin{array}{l}\text { Monitor the Key Performance on } \\
\text { regular basis }\end{array}$ \\
\hline 4 & Infection Prevention and Control & 9 & Resource Requirements \\
\hline 5 & $\begin{array}{l}\text { Case Management and continuity of } \\
\text { essential services }\end{array}$ & & \\
\hline
\end{tabular}

Centres for Disease Control and Prevention (CDC), United States of America, comes up with formation of members of the planning committee which include the following: (Develop a list of committee members with the name, title, and contact information for each personnel category shown in Table 2).

Table 2: Centres for Disease Control and Prevention (CDC) recommended formation of Committee Members for structure planning and decision making at Nursing Homes

\begin{tabular}{|l|l|l|l|l|}
\hline SN & \multicolumn{1}{|c|}{ Member Representative } & Name & Title & Contact Information \\
\hline 1 & Facility administration & & & \\
\hline 2 & Medical director & & & \\
\hline 3 & Director of Nursing & & & \\
\hline 4 & Occupational health & & & \\
\hline 5 & Staff training and orientation & & & \\
\hline 6 & Engineering/maintenance services & & & \\
\hline 7 & Environmental (housekeeping) services & & & \\
\hline 8 & Dietary (food) services & & & \\
\hline 9 & Occupational/rehabilitation/physical therapy services & & & \\
\hline 10 & Facility staff representative & & & \\
\hline 11 & Transportation services & & & \\
\hline 12 & Purchasing agent & & & \\
\hline 13 & Other member(s) as appropriate & & \\
\hline
\end{tabular}

Source: CDC (2020)

Each country has their own models for preparedness and response for disaster as per recommendation by WHO and its requirements. It may different in process but the functioning is somehow similar in all.

The Conceptual Framework for Preparedness and Response is basically refers to understanding of situation assessment, response of strategy and monitoring framework and arrangement of resource requirements. This is the universal model of disaster management in which many countries are following. The difference can be there in implementation mechanism.

World Health Organization declared the coronavirus outbreak as a global pandemic on 11 March after an infectious disease is passing easily from person to person in many parts of the world at the same time. According to The New York Times (2020), the coronavirus pandemic has sickened more than 650,100 people, according to official counts. As of Saturday evening of $28^{\text {th }}$ March 2020, at least 30,313 people have died, and the virus has been detected in at least 171 countries. The details on how the corona virus has spread is shown in the Figure 1. 
Figure 1: Corona virus Spreading Map: Tracking the Global Outbreak

\begin{tabular}{|c|c|c|c|}
\hline & CASES & DEATHS & $10 \quad 100 \quad 1,000$ \\
\hline \multirow[t]{2}{*}{ United States } & 123,072 & 2,126 & 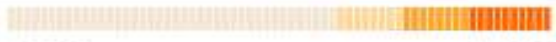 \\
\hline & & & $\tan 22$ \\
\hline Italy & 92,472 & 10,023 & (1) \\
\hline Mainland China & 81,394 & 3,295 & 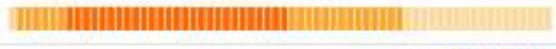 \\
\hline Spain & 72,248 & 5,690 & 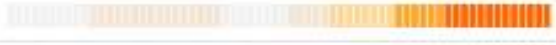 \\
\hline Germany & 48,582 & 325 & (14) \\
\hline France & 37,575 & 2,314 & 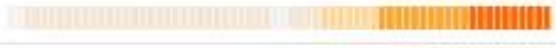 \\
\hline Iran & 35,408 & 2,517 & 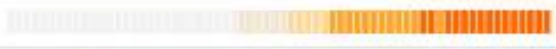 \\
\hline U.K. & 17,089 & 1,019 & 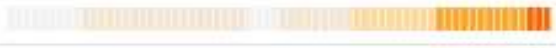 \\
\hline Switzerland & 13,213 & 235 & ||||||||||||||| \\
\hline Netherlands & 9,762 & 639 & (2) \\
\hline
\end{tabular}

Source: The New York Times (2020) Data are based on reports at the time of publication.

The Corona virus spreading map of figure 1 shows how quick the virus has travelled and affected the countries. During the January 22, the spread was much lower while the moving to March 27, the spread was intense affecting the thousands of population. The figure clearly shows how Mainland China has controlled the spreading of virus and how intense the spreading is in other countries. The US overtook China in terms of confirmed cases on Thursday, 26 March, 2020 according to figures collated by Johns Hopkins University. The true figure for the number of people with coronavirus is thought to be much higher as many of those with milder symptoms have not been tested and counted.

\section{China's Quick Model of Controlling Pandemic over US, Italy and South Korea.}

China is already experienced in controlling such pandemic situation from the time of outbreak of SARS in 20022003. This time it is not that much difficult for government to set up large scale surveillance system in identifying and following up the suspected and infected people (Business Insider, 2020). There is already existence of special fever clinic, which has been widespread in the time of SARS outbreak in 2002. In China, 50 percent of their consultations are done online, medicines are supplied through online and making the regular health services going etc. The health services is so much large and quick it took not more than 5 to 10 minutes to do the CT Scan while usually it takes more than one to two hours in US. It did not take time for China to create new hospitals and even use the existing hospital for Corona and sealing the area. This is true that in such pandemic period, faster you are in identifying and tracking the people and isolate them, the more quickly you can control the situation and similar thing has happened in China. China's social media also did a great work on counter to fake news and other disease misinformation on internet but similar things was not realised in Facebook and Twitter. Many Chinese people do not get Twitter or Facebook to share the experience of virus as such websites are blocked down. China's immediate stopping of regular transportation was also one of the main reasons for stopping the spread while in US, Italy, Spain and other countries this decision seemed to be weak (BBC, 2020); (Business Insider, 2020).

China had been stricter for enforcing the rules, in lock down period, the security guards are on petrol on every residence to make sure citizens do not violate the government's measures but such approach was not there in other nations and even cannot be done in US and other European countries. Food were delivered to fifteen million citizens through online during the period as people from China cannot move out from home to purchase supplies. Different part of providence sent the more than 40,000 medical workers and volunteers to control the situation and even high way workers, receptionist and many people learned and start examining and even teaching visitors to identify the corona symptoms while this was not possible for US, Asia or other European countries. South Korea finally in situation of controlling as there are number of cases fall in the last couple of weeks while Italy is still ramping up measures to control and slow down the spread of virus as there is already shortage of hospital beds and medical supplies as there is already situation at some places for doctors to choose which corona patients to save first. The United States has ramped up testing for the virus from last week and tested more than half of 
million people but there is no such national wide lockdown but have introduced measures to try to cope with the growing number of cases, closing restaurants, bars, cinemas, hotels and gyms. President Trump has ordered General Motors to make ventilators for coronavirus patients, by enforcing companies to make products for national defence. China mandated a country shutdown while for US and other developed nations, such nationwide shutdown is difficult (BBC, 2020); (Business Insider, 2020).

Although South Korea didn't follow lockdown method, it made quick preventive and curative method. Identification of this viral disease is made within an hour by using telephone booth and public place in each nook and corner of the country. However, Italy and US didn't make preparation once COVID-19 outbreak was there in China and still rejects country lockdown method. If the situation is under control, it is not necessary but we shouldn't make alarming and looming over problem. Italy people didn't delink socialization and violated lockdown request of the government. International border was not sealed in time. Socialization went in regular basis that caused devastation in Italy. Spain is also hardest hit from these viral calamities. When this disease became the threat against human domain across the globe, different pharmaceutical companies and developed countries are in collaboration and coordination to learn their experiences and medication system.

The overall controlling mechanism for China seems to be fast, speedy and strict but such controlling mechanism been commented as offensive by many individuals and Institutions (Nature, 2020). As per BBC (2020) China is saying that it has now stopped the spread of the disease and the authorities have started to allow some access to Wuhan, the city in Hubei province where the outbreak began. After more than two months of isolation, people were allowed to enter the city by train - but not to leave.

\section{Nepal's Response to the COVID-19 Outbreak}

World Health Organization (WHO) repeatedly warned that Nepal is high risk of COVID-19. With the objective to minimize the number of people becoming infected, Government of Nepal is responding to the COVID-19 pandemic, to control the spread. Although there is high criticism on poor planning from politicians and general public, government is working to control the spread. On $20^{\text {th }}$ March, 2020 Honourable Prime Minister KP Sharma Oli address the nation on control and prevention of corona virus. Honourable minister requested to pay enough attention to hygiene; wash hands frequently with soap and water and use sanitizer, maintain social distance, avoid crowds, stay at home as far as possible, not to hoard essential goods, not to get confused and influenced by misinformation and rumours, follow the advice of doctors -experts, to be patient and restraint, remain alert but not to be panic. Since then, the regular meeting of high level coordination committee chaired by Deputy Prime Minister and Minister of Defence taking place regularly and decided further lock down the country. This initiation came after the decision been taken in India for 21 days of lockdown.

\section{Research Methodology}

The main method used for understanding the preparedness and response in this situation is through gathering information on people's experience basically understanding community's view during the lockdown period through questionnaire and semi structured interviews. These were carried out with residents living in Nepal. Selecting the local resident people from different part of the country in questionnaire allows the exploration of meanings from their own perspective. Semi-structured interviews are not a series of identical questions to be asked. Rather the interviews were guided by a series of themes which aim to ensure all the relevant topics or areas are understood and covered. How many interviewees and surveys are sufficient is always a difficult decision in qualitative and quantitative data collecting. It is also recognised that smaller numbers are necessary to achieve the kind of depth of analysis required. There is always the possibility that the next interview will reveal something completely new, but this was not possible at all cases, Coates (2010).

Both questionnaire data analysis and transcription from the interview methods takes place through "coding" methodology. In this approach, the segments of text, having the main theme, are gathered into "nodes" or "themes". The similar useful information on each "nodes" is further analysed. This method of coding analysis is widely used in qualitative research analysis. For the purpose of analysis of primary data and secondary data, computer assisted analysis have been performed which is widely accepted technology in recent world for the data analysis. 


\section{Findings}

The study focused on understanding the perceptions of the people towards the responses of the government about the preparedness in this pandemic disaster. Majority of people feel that government is providing the accurate information on preparedness whereas suspicion towards the information provided by social sites seems to be in dilemma. Everyone feel that public awareness is only the methods to control this spreading and government is fully dedicated on this through local government. The public awareness is the only way out to cope with this pandemic since its medical remedies have not been discovered and the world in under threat and is being engulfed by the situation. The respondents agree that safety preparedness was there for front line medical staffs, doctors and proper instrument and PPE and medical staffs were self-motivated on working. However medical staff are self-motivated (more than 40 doctors died in Italy) but again a small portion is not agreed with this statement because some other patients are not getting treatment in hospitals throughout Nepal and hospitals have shut their gates for such patients (Nayapatrika Daily, 2020). The respondents agree that government had not enough testing kits as seventy five percent of the respondents are hopeless since there is no sufficient availability in Nepal and government to have strength to cope the situation. This can be the reason that the people feel that Government cannot control the situation as there is presence of one virology lab throughout the nation and testing kits have not reached to the hospitals yet. The majority of respondents were disagreed about good testing mechanism in Nepal as they are not trust worthy. The budget allocated to fight the situation is not sufficient, in such underdeveloped political system budget allocated in the beginning to fight such calamities less and same things are happening. Strategic preparedness is not sufficient because countries like Nepal are associated with the reflection of mentality of their more uneducated population that they depend in their destiny for miracle to be happened and do not have any plan to fight such pandemic. Majority of population are angry with the working system and mechanism of government as there is no emergency clinics set up to check cases in home and in locality like China, Singapore and Korea except only one till now and there are no even health posts available for people in remote areas as many people have returned from third country and private hospitals are closed in the fear of Corona and safety. Many agree that government need to immediately regularize the flow the necessity goods for sustaining the population. Almost all the respondents are with the government suggest to implement some strict rules and develop more effective system to control the situation by gathering cooperation and help from NGOs, INGOs and other countries as much as possible.

Figure 2: Preparedness of Government of Nepal

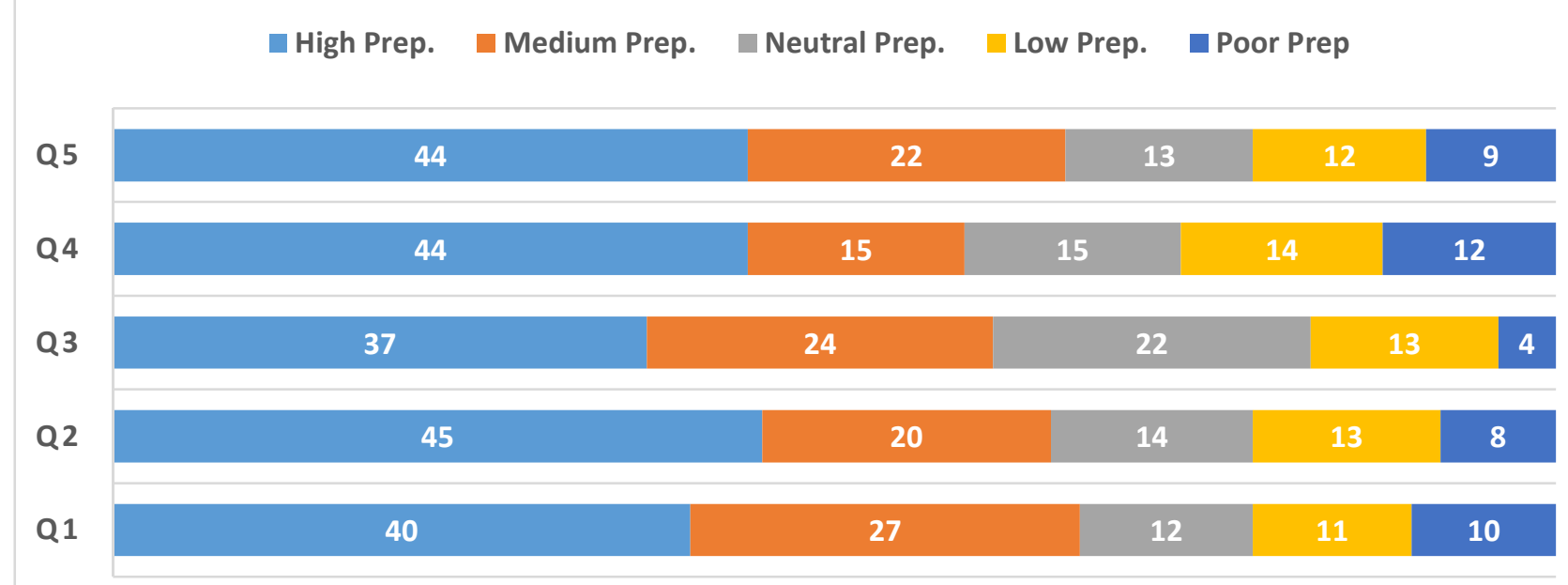

Note: Q1 = Providing supportive packages for Business to ensure proper functioning of supply chain, Q2 = Enforcements of 618 private hospitals to come into operation, Q3 = Need to come up with supportive plans for general public and business houses, $\mathrm{Q} 4=$ Gurantee of providing basic requirements for low and daily earning people, Q5 = Need of NGOs and INGOs to launch awareness program immediately.

Similarly, respondents feel that Government must provide Economic supportive packages for Business to ensure proper functioning of supply chain; Government must enforce 618 private hospitals to come into operation with proper safety equipments; Government must inform to business people about time shift for tax payments; early payments of pension money for retired; early payments of old age pension etc as supportive plan; NGOs and INGOs need to launch awareness program immediately; country office of intergovernmental agencies need to be 
encouraged and make them active to support government of Nepal and general public to follow preventive and curative care.

The details of qualitative analysis from verbatim interview from medical experts are shown in the Table 3.

Table 3: Verbatim Interview from Medical Experts

\begin{tabular}{|c|c|c|}
\hline SN & $\begin{array}{l}\text { Associated First } \\
\text { Level Concepts }\end{array}$ & Representative quotation from Interview \\
\hline 1. & $\begin{array}{l}\text { Infection prevention } \\
\text { and control }\end{array}$ & $\begin{array}{l}\text { 1. Designated hospitals need to run emergency services and OPD services } \\
\text { for } 24 / 7 \text { Hours. } \\
\text { 2. Special care for patient having high fever, cough, throat pain and shortness } \\
\text { of breath or similar sign of Pneumonia. } \\
\text { 3. Need to fix the corona special hospital though out the country under } \\
\text { Shukraraaj Tropical \& Infectious Disease Hospital, Nepal Bir Hospital, } \\
\text { B.P. Koirala Institute of Health and Science, Tribhuvan University } \\
\text { Teaching Hospital. } \\
\text { 4. Medical colleges and hospitals should follow guidelines of Nepal Medical } \\
\text { Councils and Protocol and WHO guidelines. } \\
\text { 5. Maintaining and handling the personal hygiene and sanitation as per } \\
\text { international practices for health workers, ambulances, deceased body, } \\
\text { funerals etc. }\end{array}$ \\
\hline 2. & $\begin{array}{l}\text { Top priority of } \\
\text { government }\end{array}$ & $\begin{array}{l}\text { 1. Health and safety equipment are lacking in all aspects. } \\
\text { 2. Pandemic announced by WHO and our existing capacity is too short to } \\
\text { manage. } \\
\text { 3. It is necessary to have information and logistics manager to find out } \\
\text { lacking facilities in each operated hospitals. }\end{array}$ \\
\hline 3. & $\begin{array}{l}\text { Issues of Medical } \\
\text { Staffs }\end{array}$ & $\begin{array}{l}\text { 1. PPE not available and there is acute shortage of supply even in hospitals } \\
\text { where cases are treated. } \\
\text { 2. ICU and Ventilators are lacking. } \\
\text { 3. Medical manpower is not available to meet the current demand. } \\
\text { 4. No such dedicated team leaders and despair in everything. } \\
\text { 5. Gloomy picture in technology and technician. }\end{array}$ \\
\hline 4. & $\begin{array}{l}\text { Reasons for } \\
\text { unsatisfactory Health } \\
\text { care workers }\end{array}$ & $\begin{array}{l}\text { 1. Health care workers are frightened due to ill preparation and lack of } \\
\text { logistics. } \\
\text { 2. Pandemic itself is unfamiliar situation and no such earlier trainings or } \\
\text { anticipatory drills. } \\
\text { 3. Lack of Safety First principle from government, hospital managers and } \\
\text { directors. } \\
\text { 4. Need of safety equipment, extra perks besides regular salary, insurance } \\
\text { etc. } \\
\text { 5. Grievances of health workers need to be address by related bodies. }\end{array}$ \\
\hline 5. & Suggestions & $\begin{array}{l}\text { 1. Need to tackle corona virus together, alone we fall and together we } \\
\text { success. } \\
\text { 2. Stay home, do not travel and save life. Follow all recommended } \\
\text { precaution. }\end{array}$ \\
\hline
\end{tabular}

Since the country has been facing the situation of lockdown and all the respondents have become bound to their home depending on the information sources basically social network and online news and in little extent print and digital media. Their responses reflect the availability of figures accessible to them and it certainly has the impact over the result thus obtained. A huge gap in response obtained due to the fluctuations in knowledge has been evident for a set of questionnaire. Screened or manipulated information reached to the informants or respondents in some extent influenced their response. Following figures exemplify the obtained result that expose present situation of Nepal regarding the topic about Nepal Government preparedness and Response for Pandemic Disaster. Availability and the easy access to the smart phones and internet network more than half of the population are in connection through each other and with the news and information made by any agency. 


\section{Conclusion}

The outbreak of COVID-19 is lethal to human beings, which demands support and cooperation from local community, medical practitioner, government and global community to check against it. Both preventive and curative methods are used to check the spread of this lethal COVID-19. Under preventive method, social distancing, sanitation, isolation, regular temperature and health examination, exclusion of group, country lockdown and avoidance socialization are used and under curative approach quarantine, isolation, ventilators oxygen and experimental medicines are used. Tested medication has not been developed till now. In the experience of sample respondents of Nepal, the effort of government is satisfactory for now but in case of alarming situation, it may be in questions. They argue that Nepal still lacks hi-tech equipment to control the adverse effect of it and private sector hospitals and medical staffs are suggested to use as per necessity. Personal Protection Equipments, sufficient ventilators and other physical infrastructures are not here. Diagnosis process is quite delayed because of insufficiency of the labs for medical examination. However, the government of Nepal has maintained transparency as much as possible. Preventive methods are fully implemented with sufficient awareness. Social sites information are genuine and fake both. Yet, curative method can be pretty complex for Nepal as physical infrastructures are not sufficient in case of affected persons are larger in number. But, government of Nepal made specialised hospitals in capital and various provinces of the country, which helps to check viral effect in time. As economic activities are zero, the facilities and relief packages are necessary to grant to all sectors of the country to revitalise the economy. In case of the number of cases are increased, it is alarmingly difficult to control. With the decision of country lock-down, it has both positive and negative impact. But this policy cannot sustain for longer period of time and is only short term measures.

\section{The study suggests the following recommendations:}

a. Preparedness: In this pandemic, Nepal's management been slower, after affected in India, the government had rescued students from Wuhan of China. The outcome of the research indicated that the government was having enough time to prepare for isolation, establishment of labs as required and quarantine preparation, it was not prepared. Confidence building to the general public could have done earlier by establishing testing labs, isolation places, purchasing required items or producing required, fulfil the requirements of the health workers but this could not happen. Budget and authority allocation could have been done well in advance for preparation to the local government but it took time to understand its devastating effects which has even threatened the human existence. It indicates there was no commitment in the management and when the world started panicking then Nepalese government took few initiatives.

b. Enforcement of Safety Guidelines: It was found that Nepalese need to follow strict guidelines provided by the Government which are in line with WHO. It is avoiding social gathering, using sanitizer or soap water, testing if suspected the symptoms, putting on Masks if needed to go out. Follow the guideline for quarantine and isolation.

c. Safety of Health workers: Country is in the situation of human existence, so the health workers, doctors and nurses should be working with high morale by staying safe. Creating Safe environment must be a first priority of the Hospital authority, whatever possible means to create safe working environment should be made. Health workers must ask support from the government to make you safe as much as possible but take initiative also.

d. Focus of Government: It is duty of government to regulate supplies to the people, production of Personal Protective Equipment (PPE) by any means and building confidence to the people, preparing enough ventilators in all provinces, involving private sector to produce whatever required, engaging private parties to work on producing medical testing to regularize its availability. Government need to come with immediate supportive package to its people and to tourism industries. Creating safely working environment to the main producers and farmers so that they are encouraged to produce basic food items. All facilities should be provided to maintain social distancing, using sanitizer, putting on masks while working everywhere. Government should immediately mobilizing rapid action medical team in all provinces. Government should ensure that there is enough medicines for cough, fever, pneumonia and may others. For safety, medical rescue team should be in proper safety gears. Government must come up 
with Stimulus package for the reviving the industries. Similarly Testing should be intensify and publish the date frequently about the situation and take the decision.

e. Focus of Private Sectors: Basically the private sector should come forward to support the initiative of the government, now humanity is in stake. Invest in research facility in collaboration with the government and give attention in production and distribution. The economic recession should be combating through self-dependent on basic needs. PPE production, NP95, general mask, hospital furniture and producing simple equipment as well should be given priority in this situation. The financial package should be used to revive the industries and business and to sustain the life as well.

f. Support of International Community: The COVID-19 showed that the world is really a village, if there is human crisis in one area the whole world is affecting quickly. So the International organizations need to invest to protect the people. INGO/ NGO should be concentrated to train health workers, uplifting their morale, creating awareness to people on the transmission of COVID-19. Diverting the program from regular to Combating COVID 19 in the program is strongly necessary. Supporting for combating COVID-19 should be made first priority in Nepal and it will be the support to the humanity.

g. Capacity to Handle Large Number of Patients: Immediately special hospitals should be developed for isolations in all provinces, if the space is required houses could be taken in lease, prefab hospitals should be built overnight. Proper planning required to combat with COVID-19 in infrastructures preparation in support with private sectors. Built all prefab hospitals in public land as referral hospital for COVID-19, India has prepared coaches of trains similarly Nepal should learn how to go for it.

This research is only limited on the preparedness and response of the government of Nepal to tackle the effect of COVID-19. Further research can be conducted on economic impact, method of relief and economic fund, crisis handling in large number of case, health hazard of experimental medication, psychological impact of medical practitioner and many more. It has open room to link all aspect of society in relation with sociological, psychological, anthropological, cultural and technological implication of the COVID-19. 


\section{References:}

BBC (2020). Coronavirus: A visual guide to the pandemic. Available at https://www.bbc.com/news/world51235105

Business Insider (2020). China took at least 12 strict measures to control the coronavirus. They could work for the US, but would likely be impossible to implement. Available at https://www.businessinsider.com/chinascoronavirus-quarantines-other-countries-arent-ready-2020-3\#while-staying-home-its-been-relatively-easy-forchinese-people-to-get-extra-food-and-supplies-9

CDC (2020). Coronavirus. Available at shttps://www.cdc.gov/coronavirus/2019-ncov/index.html

Huang C, Wang Y, Li X, Ren L, Zhao J, Hu Y, et al. (2019). Clinical features of patients infected with 2019 novel coronavirus in Wuhan, China. The Lancet.

Letko M, Munster V. (2020). Functional assessment of cell entry and receptor usage for lineage B $\beta$ coronaviruses, including 2019-nCoV.

Medicine Net (2020). Definition of Pandemic. Retrieved 28 March 2020, from

https://www.medicinenet.com/script/main/art.asp?articlekey=4751

Nature (2020). What China's coronavirus response can teach the rest of the world? Available at https://www.nature.com/articles/d41586-020-00741-x

Nayapatrika Daily (2020). Available at https://www.nayapatrikadaily.com/e-paper.php

The New York Times (20202) Coronavirus Map: Tracking the Global Outbreak. Available from https://www.nytimes.com/interactive/2020/world/coronavirus-maps.html

WHO (2020). Introduction to nCoV. Retrived 28 March 2020, from https://openwho.org/courses/introductionto-ncov

World Health Organization (2020). WHO Statement Regarding Cluster of Pneumonia Cases in Wuhan, China Geneva 2020. Available from: https://www.who.int/china/news/detail/09-01-2020-who-statement-regardingcluster-of-pneumoniacases-in-wuhan-china

Zhu N, Zhang D, Wang W, Li X, Yang B, Song J, et al. A Novel Coronavirus from Patients with Pneumonia in China, 2019. 24 January 2020. New England Journal of Medicine. 


\section{Appendix 1: Survey Questionnaire}

\section{Preparedness:}

\begin{tabular}{|c|c|c|c|}
\hline SN & Statements & Agree & Disagree \\
\hline 1 & $\begin{array}{l}\text { I am happy with the government providing the preparedness related } \\
\text { information to its people. Whole population of Nepal is well known } \\
\text { about this pandemic. }\end{array}$ & & \\
\hline 2 & $\begin{array}{l}\text { I feel different paper media, online news and social sites are } \\
\text { providing the correct information to public related to safety. }\end{array}$ & & \\
\hline 3 & $\begin{array}{l}\text { I think public awareness is only the method to control this spreading } \\
\text { of virus and government is fully dedicated on this through local } \\
\text { government. }\end{array}$ & & \\
\hline 4 & $\begin{array}{l}\text { I believe that safety Preparedness is there for front line medical } \\
\text { staffs, doctors with proper instruments and PPT. Medical staffs are } \\
\text { self-motivated on workings. }\end{array}$ & & \\
\hline 5 & $\begin{array}{l}\text { I think government has enough testing kits for testing COVID-19 in } \\
\text { Nepal. }\end{array}$ & & \\
\hline 6 & $\begin{array}{l}\text { I think if there is wide spread, then Nepal Government can easily } \\
\text { control the situation. }\end{array}$ & & \\
\hline 7 & $\begin{array}{l}\text { I think, there is good testing mechanism in Nepal. Government } \\
\text { testing is trustworthy. }\end{array}$ & & \\
\hline 8 & $\begin{array}{l}\text { There is enough Virology Lab (like Teku Lab) in all providences } \\
\text { for testing. }\end{array}$ & & \\
\hline 9 & $\begin{array}{l}\text { I think there is enough ICU and ventilators in all provinces in } \\
\text { Nepal. }\end{array}$ & & \\
\hline 10 & $\begin{array}{l}\text { I believe government is utilizing the private hospitals in this } \\
\text { difficult time for enough beds and infrastructure. }\end{array}$ & & \\
\hline 11 & $\begin{array}{l}\text { I think more training for this pandemic is required for medical staffs } \\
\text { in Nepal. }\end{array}$ & & \\
\hline 12 & $\begin{array}{l}\text { I think, government is daily monitoring and data collecting } \\
\text { mechanism centrally in Nepal for taking the corrective actions } \\
\text { throughout Nepal. }\end{array}$ & & \\
\hline 13 & $\begin{array}{l}\text { Tourism Industry and Remittance is highly affected and } \\
\text { government has already come with supportive package to control } \\
\text { the multiplier effect. }\end{array}$ & & \\
\hline 14 & $\begin{array}{l}\text { I believe, Government is already planning to regularize Productions } \\
\text { and supply chain management to control the situation so that } \\
\text { necessity productions are available in market. }\end{array}$ & & \\
\hline 15 & $\begin{array}{l}\text { I think the government is providing the situation "someone is there" } \\
\text { feelings to the people in this difficult situation. }\end{array}$ & & \\
\hline
\end{tabular}

What are your recommendations for government to control the situation? Please give level of priority. $1=$ Highest, $2=$ Medium, $3=$ Neutral, $4=$ Low and $5=$ Poor

\begin{tabular}{|r|l|r|}
\hline \multicolumn{1}{|c|}{ SN } & \multicolumn{1}{|c|}{ Statements } & Rating \\
\hline a. & $\begin{array}{l}\text { Government must provide Economic supportive packages for } \\
\text { Business to ensure proper functioning of supply chain. }\end{array}$ & \\
\hline b. & $\begin{array}{l}\text { Government must enforce 618 private hospitals to come into } \\
\text { operation. Government must provide the safety equipment to } \\
\text { private sectors as well. }\end{array}$ & \\
\hline
\end{tabular}




\begin{tabular}{|r|l|l|}
\hline c. & $\begin{array}{l}\text { Government must inform to business people about shift in tax } \\
\text { payments, early example 4 months payments of pension money } \\
\text { and old age pension. }\end{array}$ & \\
\hline d. & $\begin{array}{l}\text { Social security Fund must be active in this time for the } \\
\text { employees for support. Low subsidies need to be given for low } \\
\text { income people. }\end{array}$ & $\begin{array}{l}\text { Labour (low paid workers), taxi drivers, transport drivers, bus } \\
\text { drivers etc need to be given guarantee for enough foods and } \\
\text { other essentials through different supportive packages. }\end{array}$ \\
\hline e.
\end{tabular}

Do you agree or disagree. Please Answer Yes or No to the following questions.

\begin{tabular}{|c|c|c|c|}
\hline SN & Statements & Yes & No \\
\hline 1 & $\begin{array}{l}\text { Is government transparent in providing information in this } \\
\text { situation? }\end{array}$ & & \\
\hline 2 & Has government allocated enough funds to all provinces? & & \\
\hline 3 & $\begin{array}{l}\text { Is overall strategic preparedness and response of government is } \\
\text { satisfactory? }\end{array}$ & & \\
\hline 4 & $\begin{array}{l}\text { Is private hospitals are providing the services for other diseases to } \\
\text { general people? }\end{array}$ & & \\
\hline
\end{tabular}

Qualitative Interview Questions for Experts working in medical field, to cover the following themes.
a. Infection prevention and control
b. Top priority of government
c. Issues of Medical Staffs
d. Reasons for unsatisfactory Health care workers
e. Suggestions to Government

For Comments, please send the email at: get2jyoti@gmail.com / sumanacharaya@gmail.com

Important Notice: The views, thoughts, and opinions expressed in the text belong solely to the author, and not necessarily to the author's employer, organization, committee or other group or individual. 